\title{
ANALISIS IMPLEMENTASI PENGENDALIAN INTERNAL TERHADAP RISIKO THEFT OF CASH SIKLUS PENDAPATAN
}

\author{
Ajeng Ayu Selva Mutiara Dewi ${ }^{1)}$, Rhosalina Damayanti ${ }^{2}$, Nehemia Vedryan Ardhito ${ }^{3)}$, Febrianti \\ Kartikaningrum4), Nandha Victoria Panggabean5), Dionisius Adita Putra6) \\ ${ }^{1}$ Fakultas Ekonomika dan Bisnis, Universitas Kristen Satya Wacana \\ email: 232018143@student.uksw.edu \\ ${ }^{2}$ Fakultas Ekonomika dan Bisnis, Universitas Kristen Satya Wacana \\ email:232018046@student.uksw.edu \\ ${ }^{3}$ Fakultas Ekonomika dan Bisnis, Universitas Kristen Satya Wacana \\ email: 232018024@student.uksw.edu \\ ${ }^{4}$ Fakultas Ekonomika dan Bisnis, Universitas Kristen Satya Wacana \\ email: 232018067@student.uksw.edu \\ ${ }^{5}$ Fakultas Ekonomika dan Bisnis, Universitas Kristen Satya Wacana \\ email: 232018021@student.uksw.edu \\ ${ }^{6}$ Fakultas Ekonomika dan Bisnis, Universitas Kristen Satya Wacana \\ email: 232018107@student.uksw.edu
}

\begin{abstract}
Public organizations are expected to be able to manage their resources with adequate internal controls, to suppress the increase in cases of corruption due to misuse of assets. This research is a qualitative descriptive research conducted at GKI Tegalrejo Salatiga by collecting primary data from interviews with informants. The information obtained then processed by data reduction techniques, data presentation, and drawing conclusions. The results show that there is still a risk of theft of cash in the income cycle at GKI Tegalrejo, but it can be mitigated by controlling practices according to the concept of COSO. Some of the obstacles encountered in implementing this internal control include the church council not being fully able to understand the Tata Laksana Gereja, the absence of Standard Operating Procedures (SOP), lack of supervision on CCTV monitor, and lack of the function of the priest as a supervisor. This research is expected to be able to encourage congregational participation to assess the practice of internal control at GKI Tegalrejo Salatiga, serve as evaluation material for the GKI Tegalrejo Salatiga council to improve its internal control, and for academics, it is hoped that this research can become a reference in developing next researches.
\end{abstract}

Keywords: internal control, theft of cash, income cycle

\section{PENDAHULUAN}

Di Indonesia, masih sering ditemukan adanya kasus korupsi yang terjadi pada sejumlah organisasi sektor non publik seperti kasus korupsi senilai Rp 2,3 Miliar yang menimpa salah satu gereja di wilayah Serpong, Jawa Barat yang dilakukan oleh bendahara gereja pada tahun 2015 [1]. Sekitar tahun 2006 hingga 2010 silam, kembali lagi terjadi kasus korupsi pada Gereja Katolik Fransiskus Asisi
Paroki Panakkukang di Makassar, Sulawesi Selatan yang dilakukan oleh mantan bendahara gereja terkait dengan melaksanakan kecurangan berupa penyelewengan dana gereja sebesar Rp 4 Miliar [2].

Korupsi merupakan bentuk kecurangan yang cukup umum di Indonesia di samping penyalahgunaan aset, hal ini didukung oleh suatu penelitian pada tahun 2013, Negara Indonesia tercatat sebagai salah satu negara 
dengan tingkat penyalahgunaan aset dalam bentuk Corruption Perception Index (CPI) yang cukup tinggi dan menyebabkan Negara Indonesia menduduki peringkat ke-18 dari total 174 negara yang tergabung di dalamnya [3]. Hasil Report to The Nation yang dilaksanakan oleh ACFE (Association of Certified Fraud Examiners) menunjukkan bahwa sebesar $83 \%$ total kasus penyalahgunaan aset telah terjadi dan telah dilaporkan bahkan terus meningkat untuk setiap tahunnya [4]. Penyalahgunaan aset atau assets misappropriation merupakan salah satu bentuk klasifikasi kecurangan atau fraud pada ruang lingkup akuntansi yang hingga saat ini masih kerap ditemui terkhusus pada organisasi sektor publik (public sector) di Indonesia [5].

Penyalahgunaan aset atau assets misappropriation masih sering dijumpai dan terus meningkat pada setiap tahunnya. Peningkatan kasus penyalahgunaan aset ini dipengaruhi oleh beberapa faktor yang salah satunya adalah pengendalian internal yang diterapkan oleh suatu organisasi atau perusahaan masih kurang memadai. ACFE (Association of Certified Fraud Examiners) menyatakan bahwa lebih dari 2000 kasus penyalahgunaan aset yang terjadi pada sejumlah negara menyebabkan organisasi yang terkait mengalami kerugian mencapai 5\% dari total pendapatan yang seharusnya diterima oleh organisasi terkait [6]. Berdasarkan penelitian yang dilakukan oleh Tjungadi \& Rahadian, 2020 telah terjadi kasus penyalahgunaan kas dalam suatu organisasi nirlaba di Indonesia yang berupa penggelapan dana sekitar tahun 2014 hingga 2017 silam.

Pentingnya peran organisasi publik bagi suatu negara terkhusus negara Indonesia, tentu menuntut adanya pengelolaan aset yang dapat dipertanggung jawabkan pada organisasi terkait agar dapat membantu dalam meminimalisir terjadinya kecurangan atau fraud dalam bentuk penyalahgunaan aset (assets misappropriation) yang dapat memberikan kerugian bagi organisasi terkait dan juga bagi negara
Indonesia [8]. Salah satu penyebab terjadinya penyalahgunaan aset atau assets misappropriation yang terus meningkat setiap tahunnya adalah kurang memadainya fungsi atau peranan dari pengendalian internal yang menjadi dasar utama dalam meminimalisir terjadinya risiko kecurangan terhadap aset suatu organisasi tertentu [9]. Sistem pengendalian internal merupakan suatu sistem yang dirancang untuk melaksanakan fungsi pengawasan terkait dengan aktivitas operasional hingga finansial perusahaan agar dapat berjalan sesuai dengan yang seharusnya demi mencapai tujuan organisasi atau perusahaan tersebut [10]. Dengan adanya fungsi dari sistem pengendalian internal ini diharapkan dapat membantu dalam menopang kinerja suatu organisasi atau perusahan agar dapat berjalan sesuai dengan yang diharapkan serta dapat membantu dalam memitigasi terjadinya risiko kecurangan yang mungkin terjadi [11].

Endiana, 2020 menyatakan bahwa dengan adanya sistem pengendalian yang diterapkan dalam suatu organisasi atau perusahaan dapat menjadi parameter atau tolak ukur keberhasilan suatu organisasi atau perusahaan dalam memitigasi terjadinya risiko kecurangan atau fraud. Namun berdasarkan hasil pemeriksaan yang dilaksanakan oleh BPK (Badan Pemeriksa Keuangan) Republik Indonesia, menyimpulkan bahwa masih terdapat sejumlah organisasi atau perusahaan yang menerapkan sistem pengendalian internal dengan kurang maksimal atau dengan kata lain sistem pengendalian internal yang diterapkan masih belum memadai sehingga pencegahan terhadap kecurangan atau fraud masih belum dapat dilaksanakan dengan maksimal [12].

Penelitian ini dilakukan di GKI Tegalrejo Salatiga, sebagai salah satu entitas publik yang bergerak dalam bidang pelayanan keagamaan. Pokok persoalan yang menjadi pusat perhatian dalam penelitian kali ini adalah implementasi pengendalian internal terkait dengan kemungkinan terjadinya 
penyalahgunaan aset atau assets misappropriation berupa theft of cash pada siklus pendapatan di GKI Tegalrejo Salatiga. Untuk menjawab persoalan penelitian yang ada, dirumuskan bahwa tujuan dari penelitian ini adalah untuk menganalisis bagaimana implementasi sistem pengendalian internal menurut Committee of Sponsoring Organizations of the Treadway Commission (COSO) terhadap risiko theft of cash pada siklus pendapatan di GKI Tegalrejo Salatiga. Secara teoritis, penelitian ini diharapkan mampu membantu mahasiswa dan akademisi untuk dapat memahami pelaksanaan pengendalian internal terkait risiko asset misappropriation dan juga memperkaya literatur akademis bagi penelitian selanjutnya. Secara praktis, penelitian ini bermanfaat bagi majelis dan pengurus GKI Tegalrejo Salatiga dalam mengevaluasi praktik pengendalian internal yang dilakukan, sehingga dapat dilakukan perbaikan dan meningkatkan pos pengendalian internal yang sudah baik agar dapat memitigasi risiko dengan lebih optimal. Penelitian ini juga bermanfaat bagi jemaat GKI Tegalrejo Salatiga agar jemaat dapat membantu melakukan pengawasan dan mengevaluasi kinerja pengurus GKI Tegalrejo Salatiga dalam praktik pelaksanaan pengendalian internalnya.

\section{Siklus Pendapatan}

Siklus pendapatan merupakan kegiatan penyerahan barang atau jasa untuk menerima imbalan. Siklus pendapatan mengandung informasi yang rinci terkait kegiatan penerimaan pesanan barang atau jasa, penyerahan barang atau jasa, dan penerimaan pembayaran atas barang atau jasa yang diberikan [13]. Ikatan Akuntan Indonesia melalui PSAK 45 tentang Pelaporan Keuangan Organisasi Nirlaba menyatakan operasional organisasi nirlaba berasal dari pendapatan yang diperoleh. Pendapatan ini juga akan menambah jumlah aktiva bersih tidak terikat, kecuali jika penggunaannya dibatasi oleh pihak yang memberikan dana. Pendapatan juga menjadi salah satu cara organisasi untuk bertahan hidup.
Khusus bagi organisasi nirlaba, pendapatan berasal dari kontribusi, sumbangan, dan pendapatan lain yang sifatnya bukan merupakan barang atau jasa hasil pertukaran (ISAK-35, n.d). Bagi organisasi keagamaan seperti gereja, pendapatan yang sebesar-besarnya bukanlah tujuan utama berjalannya organisasi, juga karena pendapatan diterima berasal dari persembahan yang diberikan jemaat dalam bentuk dan jenis yang berbeda [16].

\section{Kecurangan}

Kecurangan dilakukan dalam berbagai bentuk dan membawa dampak buruk bagi organisasi. Kecurangan terjadi dalam banyak bidang, baik sebagai bentuk pengambilan paksa hak orang lain maupun pembenaran atas perbuatan memperkaya diri sendiri [17]. Menurut Dinata (2018), tindak kecurangan sulit untuk dikendalikan dan merupakan tindakan tersembunyi yang tidak mudah diungkapkan. Hal ini terjadi karena beberapa pihak yang terlibat dalam lingkar kecurangan, menganggap bahwa tindakannya wajar dan sah. Kecurangan seakan sudah mengakar dan terus menjalar sebagai kebiasaan. Faktor penyebab terjadinya kecurangan saat ini berkembang menjadi The Crowe Fraud Pentagon [19]. The Crowe Fraud Pentagon ini menyebutkan bahwa lima penggerak utama tindak kecurangan adalah tekanan, kesempatan, rasionalisasi, kompetensi, dan arogansi. Arogansi menurut The Crowe Fraud Pentagon mengacu pada sikap superioritas individu dibarengi keserakahannya akan memungkinkan tindak kecurangan. Kemudian kompetensi berarti bahwa individu tersebut memiliki kemampuan untuk mengendalikan sistem pengendalian internal yang ada untuk menguntungkan diri sendiri. Danuta (2017) menambahkan konsep bahwa dengan kesadaran organisasi dalam meningkatkan pengendalian internalnya, maka sebagian besar kecurangan terjadi karena motivasi dari diri pelaku. Dalam hal ini, arogansi dan kompetensi mengambil peran besar dan saling mempengaruhi. Kompetensi 
yang dimiliki harus mampu mendukung arogansi individu tersebut, dan sebaliknya, agar tindak kecurangan bisa terjadi.

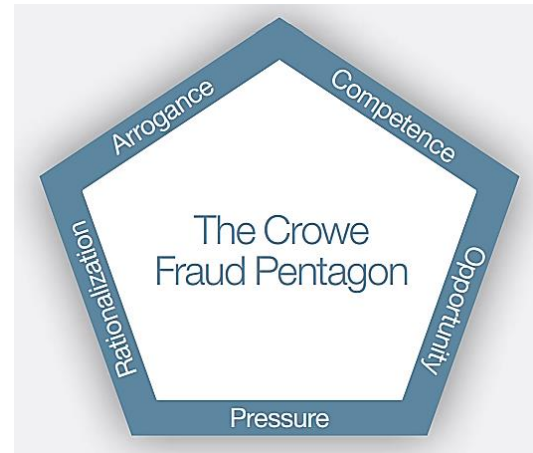

Gambar 1 The Crowe Fraud Pentagon Model

Sumber: Jonathan T. Marks (2012)

Association of Certified Fraud Examiners (2016) menyebutkan bahwa kecurangan dapat diklasifikasikan ke dalam model fraud tree. Model fraud tree oleh ACFE memiliki tiga cabang utama, yaitu korupsi, penyalahgunaan aset (misappropriation of assets), dan kecurangan pelaporan keuangan. Korupsi terjadi karena adanya skema penyalahgunaan pengaruh seorang individu di dalam organisasi dengan melanggar kewajibannya. Kemudian penyalahgunaan aset merupakan konsep seorang individu mencuri atau menyalahgunakan sumber daya organisasi yang seharusnya digunakan untuk pencapaian tujuan organisasi. Yang terakhir merupakan kecurangan pelaporan keuangan yaitu skema kecurangan yang disengaja oleh karyawan yang bertanggung jawab atas laporan keuangan dengan melakukan salah saji material dalam laporan keuangan organisasi. Menurut Udayani dan Sari (2017), tindakan kecurangan yang tidak etis dipengaruhi salah satunya sistem pengendalian internal dan pengawasan top management yang kurang efektif.

\section{Asset Misappropriation}

Asset misappropriation adalah bentuk tindak kecurangan yang paling sering terjadi dan dipengaruhi faktor tekanan, kesempatan, rasionalisasi, bahkan hingga kapabilitas pelaku [24]. Asset misappropriation dapat dilakukan oleh seluruh pihak yang terkait dengan organisasi dan merupakan salah satu isu yang berkembang dalam ranah akuntansi dan audit [25]. Asset misappropriation adalah tindakan penyalahgunaan atau pencurian aset organisasi yang sering dilakukan oleh pihak internal organisasi baik dalam jumlah kecil maupun besar [26]. Dalam penelitian Kazemian (2019), elemen dalam fraud pentagon berhubungan positif dengan terjadinya asset misappropriation. Dalam Association of Certified Fraud Examiners atau ACFE (2016) menyebutkan bahwa dalam fraud tree, komponen asset misappropriation terbagi ke dalam tujuh kategori utama dan salah satunya berupa pencurian kas. Asset misappropriation dalam bentuk pencurian kas sebagian besar dilakukan oleh karyawan atau pihak yang bertanggung jawab atas kas karena adanya kesempatan untuk melakukannya secara langsung [28].

\section{Pengendalian internal}

Pengidentifikasian sedini mungkin tindak kecurangan sudah menjadi prioritas bagi organisasi dan berkembang menjadi kebutuhan suatu organisasi [29]. Pengendalian internal merupakan suatu proses yang menjadi pedoman dalam meningkatkan keamanan data atas suatu sistem tertentu agar tujuan organisasi dapat tercapai [30]. Pengendalian internal menurut The Committee of Sponsoring Organizations of the Treadway Commission (COSO) adalah tindakan pimpinan organisasi untuk mendukung tercapainya tujuan organisasi pengelolaan risiko. Komponen pengendalian internal menurut COSO diantaranya: lingkungan pengendalian, penilaian risiko, aktivitas pengendalian, informasi dan komunikasi, serta pemantauan. Lingkungan pengendalian dideskripsikan sebagai serangkaian standar sebagai dasar pelaksanaan pengendalian internal di dalam organisasi untuk membantu pencapaian tujuan strategis, membantu menyediakan laporan keuangan yang andal, mendorong efektivitas dan efisiensi operasional organisasi, kepatuhan terhadap hukum yang 
berlaku dan mengamankan aset organisasi. Penilaian risiko menjadi dasar dalam penentuan tingkat risiko dan pengelolaan risiko. Aktivitas pengendalian berisi rangkaian tindakan seperti kebijakan dan prosedur sebagai tahap lanjutan penilaian risiko. Informasi dan komunikasi berarti bahwa informasi di dalam organisasi mampu dikomunikasikan baik kepada pihak internal maupun eksternal. Yang terakhir, pemantauan yaitu kegiatan pengawasan dan evaluasi berkala terkait pelaksanaan pengendalian internal dalam organisasi. Penelitian ini akan menggunakan lima komponen pengendalian menurut The Committee of Sponsoring Organizations of the Treadway Commission (COSO).

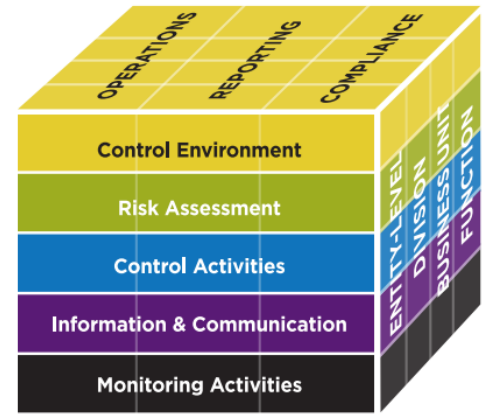

Gambar 2 Komponen Pengendalian Internal menurut COSO

Sumber: coso.org

\section{METODE PENELITIAN}

Jenis Penelitian dan Teknik Pengumpulan Data

Penelitian ini merupakan jenis
penelitian deskriptif kualitatif yang dilaksanakan di GKI Tegalrejo Salatiga. Teknik pengumpulan data untuk mendukung hasil penelitian adalah melalui wawancara dengan narasumber yang dalam hal ini dilakukan kepada pendeta GKI Tegalrejo Salatiga. Wawancara dilaksanakan dengan mempersiapkan kerangka pertanyaan yang dapat dikembangkan secara situasional. Untuk memperkuat bukti penelitian, teknik dokumentasi juga digunakan selama proses wawancara dengan narasumber. Dokumentasi dilakukan dengan mencatat hasil wawancara, merekam proses wawancara, dan mengambil beberapa foto dengan narasumber serta kondisi lingkungan di sekitar objek penelitian.

\section{Teknik Analisis Data}

Penelitian ini menggunakan teknik analisis data tiga rangkaian. Yang pertama yaitu reduksi data, kedua penyajian data, dan kemudian dilakukan penarikan kesimpulan. Reduksi data dilaksanakan dengan memilih dan meringkas data dari berbagai dokumentasi yang ditemukan di lapangan. Dalam proses ini, dilakukan pembuangan data-data yang kurang relevan dengan penelitian selain itu juga menggolongkan, memusatkan, meringkas, dan mengorganisasi data sedemikian rupa yang terus berlanjut sampai kesimpulan penelitian dapat dibuat. Setelah reduksi data, kemudian adalah penyajian data yang dilakukan dengan penyusunan dan pengklasifikasian data, untuk membantu proses penarikan kesimpulan. Dalam penelitian ini, penyajian data berbentuk teks naratif yang berisi temuan di lapangan. Proses terakhir merupakan penarikan kesimpulan. Pada proses ini, penelitian berfokus pada data yang telah terpilih untuk dilakukan analisis lebih dalam. Hasil penelitian akan terlebih dahulu dilakukan verifikasi dengan hasil wawancara dan temuan di lapangan serta permintaan konfirmasi kepada narasumber.

\section{HASIL DAN PEMBAHASAN Gambaran Objek Penelitian}

GKI Tegalrejo Salatiga adalah satu gereja di Salatiga, Jawa Tengah yang juga merupakan bagian keanggotaan dari GKI Klasis Magelang. Gereja ini telah berdiri sejak tahun 1966 menempati salah satu rumah warga di Karang Kepoh, Tegalrejo, Argomulyo, Kota Salatiga, Jawa Tengah Pada tahun 1972 telah didirikan rumah ibadah di Karang Kepoh dan kemudian pada tahun 1993 mulai didirikan kembali gedung gereja baru yang terletak di Jl. Tegalrejo Raya No 66A Salatiga. Jumlah anggota jemaat terus mengalami peningkatan dari waktu ke waktu dan mencapai 200 hingga 
300 orang yang terdaftar sebagai anggota jemaat gereja. Sejak tahun 2013 pendeta aktif di GKI Tegalrejo Salatiga adalah Pdt. Raharjo Widhipangreksa.

Aktivitas operasional GKI Tegalrejo Salatiga didukung dengan perolehan pendapatan GKI Tegalrejo Salatiga yang bersumber dari persembahan yang jemaat dan simpatisan serta merupakan satu-satunya sumber pendapatan bagi gereja. Persembahan di GKI Tegalrejo Salatiga di bagi ke dalam beberapa jenis di antaranya: persembahan mingguan, persembahan bulanan, persembahan syukur, persembahan persepuluhan, persembahan rumah emeritus, persembahan seribu rumah Tuhan, dan persembahan perantara. Pemberian persembahan dapat dilakukan secara langsung maupun melalui transfer bank.

Di tengah pandemi Covid-19, GKI Tegalrejo Salatiga juga memberikan kelonggaran bagi jemaat yang hendak memberikan persembahan untuk dapat mengantarkan persembahannya ke gereja selama hari kerja. Perolehan persembahan akan dikelola langsung oleh bendahara majelis GKI Tegalrejo Salatiga. Persembahan yang diberikan secara langsung akan disimpan dalam bentuk cash on hand, sementara persembahan melalui transfer bank akan disimpan dalam bentuk cash on bank. Karena persembahan adalah satusatunya sumber pendapatan bagi GKI Tegalrejo Salatiga, maka diperlukan pengendalian yang tepat dan memadai dalam pengelolaan perolehan persembahan ini.

\section{Siklus Pendapatan di GKI Tegalrejo Salatiga}

Sumber pendapatan utama GKI Tegalrejo Salatiga adalah persembahan yang diberikan oleh jemaat dan simpatisan. Konsep persembahan yang dimaksud disini hampir seperti donasi bagi organisasi publik lainnya, seperti yayasan. Karena pendapatan ini bersifat tidak memaksa, maka jumlah persembahan juga tidak mampu ditentukan secara pasti oleh gereja.

"Pendapatan kita hanya dari persembahan, biasanya bentuknya uang.
Jumlahnya juga beda-beda, gak bisa dipastikan. Kalau disini persembahan itu ada beberapa jenisnya. Jadi gak cuma persembahan minggu biasa, ada persembahan syukur, persembahan perantara, persembahan persepuluhan. Ya sama kaya di GKI Salatiga."

Perbedaan jenis persembahan yang ada di GKI Tegalrejo Salatiga merupakan salah satu fasilitas bagi jemaat yang ingin memberikan persembahan untuk dapat lebih fokus dengan tujuan pemberian persembahan. Akan tetapi, secara keseluruhan, kecuali persembahan perantara, maka jenis-jenis persembahan yang ada akan digunakan untuk operasional dan pembangunan gereja. Siklus pendapatan di GKI Tegalrejo Salatiga dimulai dari proses penerimaan persembahan, penghitungan dan penyimpanan persembahan, pencatatan persembahan, dan pelaporan penerimaan persembahan.

Proses penerimaan persembahan dapat dilakukan secara tunai maupun transfer melalui bank dan $Q R$ Code. Waktu dan jumlah pemberian persembahan juga tidak dibatasi. Tetapi proses penghitungan dan pencatatan persembahan dilakukan di hari Jumat setiap minggunya. Bendahara majelis menjadi penanggung jawab proses penghitungan dan pencatatan persembahan hingga nanti proses pelaporan penerimaan persembahan.

"Selama pandemi ada kelonggaran kapan masukin persembahan. Gak harus Minggu. Silakan mau masukkan kapan saja kotaknya ya disini ini terus. Kalau mau transfer juga bisa. Rekening kita tulis di warta. Di Youtube juga ada."

Berdasarkan kutipan wawancara dengan Pdt. Widhi diketahui bahwa tidak ada batasan bagi jemaat yang ingin memberikan persembahan. Persembahan dapat diberikan kapan saja dan melalui beberapa media yang difasilitasi gereja. Persembahan yang diperoleh secara tunai akan disimpan bendahara dalam bentuk cash on hand, sementara persembahan yang ditransfer akan disimpan dalam bentuk 
cash on bank. Pencatatan untuk persembahan tunai dilakukan secara manual dan akan dilakukan input ke komputer dalam bentuk laporan bulanan. Pencatatan untuk penerimaan persembahan via transfer bank hanya akan dilakukan melalui bukti rekening koran yang dikeluarkan bank. Rincian penerimaan persembahan akan dilaporkan secara mingguan kepada jemaat melalui warta jemaat yang dapat diakses secara online melalui website gereja maupun didapatkan di pintu depan gereja setiap hari Minggu. Sesuai dengan penelitian (Bigky \& Rahmah, 2019), yang menjelaskan bahwa bagi organisasi keagamaan seperti gereja, pendapatan yang sebesar-besarnya bukanlah tujuan utama berjalannya organisasi, pun demikian arti persembahan sebagai pendapatan di GKI Tegalrejo Salatiga. Meskipun demikian, pengelolaan siklus pendapatan di GKI Tegalrejo Salatiga harus dilakukan dengan optimal dan meminimalisir risiko yang ada agar operasional gereja tidak terganggu.

\section{Risiko Theft of Cash}

Setiap organisasi pasti memiliki risiko dalam operasionalnya. Berdasarkan penelitian yang dilaksanakan pada GKI Tegalrejo Salatiga, risiko terbesar yang dapat terjadi pada GKI Tegalrejo Salatiga dalam pelaksanaan aktivitas organisasi yang terkait dengan siklus pendapatan adalah risiko kecurangan berupa pengambilan persembahan yang tidak sah (theft of cash) oleh pihak internal gereja. Risiko ini muncul hampir di setiap tahap pengelolaan siklus pendapatan gereja. Risiko ini disebabkan kurangnya otorisasi dan pemisahan tugas yang jelas antar bendahara, keterlibatan divisi lain dalam urusan keuangan, dan tidak tersedianya Standar Operasional Prosedur (SOP) dalam pengelolaan persembahan. Risiko theft of cash ini akan menghambat proses operasional di GKI Tegalrejo Salatiga. Dalam kepengurusan gereja, dibentuk divisi kebendaharaan dengan anggota Ibu Estu dan Ibu Tri, namun pada kenyataannya pengelolaan persembahan dapat diketahui dan melibatkan hampir semua pengurus gereja, termasuk pendeta. Hal ini dibenarkan oleh Pdt. Widhi selaku narasumber utama.

"Sebenarnya pendeta itu gak boleh pegang apa-apa, kami memantau saja. Tapi saya kebetulan ada di gereja kecil, jadi saya banyak terjun di hampir semua bidang. Ada apa apa bareng-bareng, jadi semua tau semua."

Dalam satu siklus pendapatan ini, terdapat beberapa bagian yang menyebabkan potensi risiko theft of cash. Pertama, risiko theft of cash saat tahap penerimaan persembahan. Risiko ini berupa pengambilan amplop persembahan pada kotak persembahan yang terletak di dalam gedung gereja dalam jangka waktu setelah ibadah hingga proses penghitungan persembahan, hari Jumat minggu berikutnya.

"Persembahan itu ada kantong merah, hijau, sama biru. Tapi selama pandemi kita pakai satu kotak persembahan aja."

Selama penelitian, Pdt. Widhi mengatakan bahwa upaya menghadirkan satu kotak persembahan ini adalah untuk mengurangi kontak fisik akibat kantong persembahan yang diedarkan. Penyediaan kotak persembahan di dalam gedung gereja berbentuk seperti mangkok besar yang terbuka agar mudah bagi jemaat untuk memasukkan persembahan dan mengurangi risiko sentuhan fisik antar jemaat. Akan tetapi, dari kemudahan yang diberikan justru memunculkan risiko theft of cash karena mempermudah proses pengambilan amplop persembahan. Risiko ini semakin mungkin terjadi dikarenakan setelah ibadah selesai, amplop persembahan yang sudah terkumpul tidak diamankan dan dibiarkan berada dalam kotak persembahan yang terbuka.

Temuan di objek penelitian adalah bahwa setelah ibadah selesai, pendeta, majelis, dan jemaat akan meninggalkan gedung gereja dan akan menyisakan beberapa petugas multimedia, petugas ibadah, dan penatalayanan gereja di dalam gedung gereja. Dengan kesempatan yang ada, memungkinkan theft of cash dilakukan oleh pihak internal gereja pada 
saat ini, hingga penguncian gedung gereja pasca ibadah. Penguncian gedung gereja dilakukan oleh penatalayanan, kunci gereja juga disimpan di Kantor Tata Usaha (TU) gereja, dan tidak dilakukan penghitungan serta pendataan amplop persembahan yang ada di dalam kotak persembahan, sehingga risiko pengambilan amplop persembahan (theft of cash) sangat mungkin dilakukan.

Risiko theft of cash juga terjadi pada penerimaan persembahan melalui transfer bank dan scan $Q R$ code dengan dilakukannya penarikan saldo tidak sah karena ketiadaan pencatatan manual oleh bendahara, penghitungan, dan pengecekan saldo bank maupun $e$-wallet secara berkala.

"Rekening kita hanya satu, pakai BRI. Digunakan untuk transfer persembahan juga. Pencatatan transfer bank nanti dimasukkan ke laporan laba rugi to. Ada rekapannya pake rekening koran yang muncul di email. Kalo pake QRIS kita gak tahu identitasnya."

Terkait dengan $Q R$ Code, dari aplikasi $e$-wallet yang digunakan tidak menyediakan laporan berkala. Bahkan tidak tercantum identitas lengkap pihak yang melakukan pengiriman atau penarikan dana. Terkait transfer bank, otorisasi rekening sepenuhnya ada di tangan bendahara. Namun demikian, bendahara majelis juga tidak melakukan pengecekan rekening koran secara berkala sehingga tingkat controlling saldo rekening bank rendah.

Dalam proses penghitungan persembahan, risiko theft of cash muncul ketika proses penghitungan amplop persembahan berasal dari kotak persembahan di gedung gereja dan kotak persembahan dari kantor TU gereja. Risiko ini berupa pengambilan amplop persembahan secara tidak sah selama proses penghitungan, karena belum tersedia rincian pencatatan penerimaan persembahan dan jumlah amplop yang tersedia cukup banyak.

$\begin{array}{cccc}\text { "Ada } & d u a & \text { bendahara sama } \\ \text { penatalayanan nanti (Kak Melben) } & \text { yang }\end{array}$ menghitung persembahan. Pencatatan seperti akuntansi biasa ada pemasukan ada pengeluaran. Yang mengelola bendahara. "

Setelah proses penghitungan, persembahan yang diterima secara tunai (melalui kotak persembahan) tidak disetorkan ke bank. Uang persembahan akan disimpan dalam bentuk cash on hand dan dibawa oleh bendahara. Pdt. Widhi menyampaikan bahwa penyimpanan kas di bank hanya dilakukan pada kas yang memang dikirim ke bank melalui persembahan transfer.

"Persembahan yang udah dihitung nanti ya disimpan bentuknya tunai dipegang bendahara. Yang ditransfer di bank ya tetap di bank."

Risiko terkait theft of cash ini dapat terjadi pada saat penyimpanan cash on hand atas uang persembahan. Risiko ini juga dimungkinkan terjadi karena tidak tersedianya pembagian tanggung jawab yang jelas antara penanggung jawab bendahara pengelola cash on hand dengan bendahara yang bertanggung jawab dalam menyimpan catatan penerimaan persembahan.

Setelah penghitungan persembahan, akan melakukan pencatatan penerimaan persembahan secara manual di dalam buku kas gereja. Selama penghitungan dan pencatatan persembahan, pendeta akan menjadi pengawas namun tidak rutin karena cukup padatnya jadwal pelayanan pendeta. Terkait dengan proses pencatatan penerimaan persembahan, risiko theft of cash muncul dengan dilakukannya manipulasi data pencatatan dengan understatement pencatatan dan dilakukan pengambilan persembahan secara tidak sah.

Dalam proses penghitungan, bukti pencatatan hanya ada pada catatan manual, tidak tersedia kuitansi. Sehingga proses manipulasi data dapat dilakukan, hal ini sejalan dengan konsep The Crowe Pentagon Fraud yang menyebutkan bahwa kesempatan merupakan salah satu faktor yang mempengaruhi tindak kecurangan. ACFE juga menambahkan bahwa 
karyawan yang bertanggung jawab atas laporan keuangan mungkin juga akan melakukan kecurangan dengan melakukan salah saji material dalam laporan keuangan organisasi.

"Nanti kita juga akan masukin transaksi ke komputer nanti pos-pos jurnalnya terkomputerisasi dan bisa dilihat realisasi anggaran berapa persen. Bendahara kita sepuh, gagap teknologi, yang penting bikin jurnal terus nanti baru dimasukkan ke excel dibantu istri saya kebetulan akuntan."

Dari kutipan wawancara di atas diketahui bahwa dalam pelaporan, bendahara yang sebelumnya melakukan pencatatan manual, akan dibantu oleh akuntan (istri pendeta) dalam melakukan proses posting ke laporan-laporan keuangan yang dihasilkan oleh gereja. Bendahara tidak mampu melakukan posting dan input sendiri karena keterbatasan usia dan kemampuan dalam pengoperasian teknologi yang dipakai. Risiko manipulasi data juga muncul pada tahap pelaporan ini, karena dimungkinkan bahwa akuntan akan bekerja sama dengan bendahara untuk melancarkan aksi theft of cash ini.

\section{Pengendalian Internal menurut COSO}

Berdasarkan hasil pengamatan dan wawancara, beberapa bentuk pengendalian sudah diterapkan untuk mengidentifikasi, mitigasi dan meminimalisir dampak risiko akibat asset misappropriation khususnya theft of cash oleh internal GKI Tegalrejo Salatiga. Pengidentifikasian pengendalian internal dalam penelitian ini menggunakan komponen pengendalian internal menurut The Committee of Sponsoring Organizations of the Treadway Commission (COSO). Pertama adalah lingkungan pengendalian yang dideskripsikan sebagai standar dan dasar pelaksanaan pengendalian internal dalam organisasi serta sebagai payung dari semua komponen pengendalian internal. Lingkungan pengendalian di GKI Tegalrejo Salatiga sudah tersedia, melalui peraturan Gereja Kristen Indonesia (GKI) yang kemudian disebut sebagai
Tata Laksana GKI dan Tata Gereja. Ketersediaan Tata Laksana GKI dan Tata Gereja ini dijadikan sebagai payung hukum pelaksanaan operasional dan segala bentuk pelayanan di GKI Tegalrejo Salatiga.

"Kita pelaksanaan gereja itu kan ada Tata Laksana GKI. Jadi kalau sama-sama GKI ya peraturannya ada. Kita juga punya visi dan misi gereja, ada tata gereja."

Kutipan wawancara ini mengindikasikan bahwa ketersediaan Tata Laksana GKI dan Tata Gereja menjadi pedoman pelaksanaan pengendalian internal di GKI Tegalrejo Salatiga. Setiap keputusan oleh majelis dan pendeta juga didasarkan pada Tata Laksana GKI dan Tata Gereja. Komponen pengendalian internal kedua adalah penilaian risiko. Penilaian risiko di GKI Tegalrejo sudah mampu terimplementasi pada risiko theft of cash di GKI Tegalrejo Salatiga didukung dengan mampunya GKI Tegalrejo Salatiga dalam mendeskripsikan penilaian risiko ini ke dalam beberapa aktivitas pengendalian. Pada tahap penerimaan persembahan, bentuk aktivitas pengendalian yang dilakukan adalah dengan melakukan penyeragaman pemberian persembahan melalui amplop.

diamplop."

"Kita kalo persembahan pasti

GKI Tegalrejo Salatiga juga melakukan aktivitas pengendalian berupa penutupan dan penguncian gedung gereja segera setelah ibadah selesai dan tidak akan menggunakan gedung gereja kecuali untuk persiapan ibadah dan pelayanan ibadah Minggu, serta memperlengkapi dengan pemasangan CCTV di dalam dan luar gedung gereja agar aktivitas di gereja dapat terekam. Terkait dengan penerimaan persembahan melalui transfer bank, aktivitas pengendalian yang dilakukan oleh majelis GKI Tegalrejo Salatiga adalah dengan menyampaikan permintaan kepada bank untuk mengirimkan rekening koran secara berkala ke alamat email gereja. Hal ini juga disampaikan oleh Pdt. Widhi selama wawancara. 
"Ini rekening koran yang kita minta nanti dikirim terus sama bank. Jadi kita bisa control lewat sini. Ada detailnya siapa yang kirim, kapan kirim."

Persembahan yang diterima melalui transfer bank disimpan menjadi satu di satu rekening yang sama. Aktivitas ini dilakukan sebagai salah satu bentuk pengendalian agar keluar masuk kas GKI Tegalrejo Salatiga terjadi di satu rekening yang sama dan mempermudah pengumpulan bukti serta arsip transaksi. Aktivitas pengendalian terkait dengan cash on hand adalah dengan mempercayakan uang persembahan untuk disimpan oleh bendahara dan tidak ditinggalkan di gereja.

Pada proses penghitungan dan pencatatan juga dilakukan aktivitas pengendalian dengan melakukan penghitungan dan pencatatan penerimaan persembahan dilakukan dalam waktu yang sama untuk mendukung tersedianya data yang real time antara data tertulis dengan jumlah yang ada. Beberapa kali juga pendeta akan terlibat dalam penghitungan dan pencatatan persembahan sebagai pengawas.

"Persembahan nanti dihitung sama dicatat di hari Jumat. Harinya sama."

Pada tahap pelaporan, untuk memitigasi risiko theft of cash dan manipulasi data antara akuntan dan bendahara, dilakukan proses pengawasan oleh pendeta selama masa input data ke laporan keuangan. GKI Tegalrejo Salatiga juga melakukan cross check jumlah persembahan (bagi jemaat yang memberikan kode pada amplop) dan penyampaian transparansi penerimaan persembahan kepada jemaat, melalui warta jemaat yang diterbitkan setiap hari Minggu.

"Ya kita laporan terus melalui warta jemaat itu setiap minggu. Ada yang pake kode artinya dia jemaat disini jadi ada catatannya nanti."

Ketersediaan warta jemaat ini juga merupakan salah satu pengendalian internal pada komponen informasi dan komunikasi terkait siklus pendapatan dilakukan oleh majelis GKI Tegalrejo Salatiga. Penyampaian informasi penerimaan persembahan juga akan dilaksanakan tahunan melalui persidangan majelis diperluas. Persidangan ini akan dihadiri majelis, pendeta, dan jemaat.

"Nanti majelis juga akan melaporkan program dan evaluasi tahunan di persidangan majelis diperluas. Biasanya isinya evaluasi kemarin sama rencana program tahun berikutnya. Semua gereja GKI pasti gitu."

Komponen pengendalian internal menurut COSO yang terakhir adalah pemantauan, yaitu kegiatan pengawasan dan evaluasi berkala terkait pelaksanaan pengendalian internal. Proses pengelolaan persembahan akan dilakukan pengawasan oleh pendeta. Evaluasi kinerja majelis gereja dan juga pengendalian internal secara keseluruhan akan dilaksanakan di akhir tahun dalam bingkai persidangan majelis diperluas. Kegiatan pengawasan secara periodik juga dilakukan oleh klasis GKI sebagai induk gereja, untuk melihat bagaimana kondisi terkini gereja dan apakah terdapat masalah yang harus dibantu untuk diselesaikan. Kegiatan pengawasan ini disebut sebagai perlawatan rutin jemaat dan dilakukan oleh sinode GKI ke gereja-gereja Kristen Indonesia melalui masing-masing klasis.

"Pemantauan kita dari Sinode, biasanya lewat klasis. Namanya perlawatan rutin jemaat. Gunanya ya untuk memantau, menilai proporsi kekuatan jemaat dan gereja terus nanti menilai proporsi tanggung jawab bersama klasis yang bisa ditanggung gereja."

Praktik pengendalian internal dan kinerja majelis gereja seluruhnya akan dilakukan audit oleh anggota jemaat yang berprofesi sebagai akuntan atau auditor. Ketentuan ini juga termasuk ke dalam Tata Laksana GKI.

\section{Pembahasan}

Komponen pengendalian internal menurut COSO pada siklus pendapatan di GKI Tegalrejo Salatiga telah terimplementasi, namun 
masih terdapat beberapa kendala dalam pelaksanaan pengendalian internal ini. Mulai dari lingkungan pengendalian yang ada, majelis gereja tidak sepenuhnya mampu memahami Tata Laksana GKI dan Tata Gereja karena jarang dilakukan sosialisasi dan pemahaman bersama tentang peraturan ini. Akibatnya, keberadaan Tata Laksana GKI dan Tata gereja hanya sebatas sebagai peraturan tertulis dan tidak dikaji lebih jauh terkait pemaknaan dan implementasinya. Terkait penilaian risiko, kendala yang dihadapi adalah ketiadaan Standar Operasional Prosedur (SOP) pelaksanaan pengelolaan penerimaan persembahan, sehingga sulit menentukan risiko-risiko yang mungkin terjadi karena tidak tersedia panduan dan kebijakan tentang tindakan yang diizinkan atau tidak. Tingkat kepercayaan antar individu dan hubungan kekerabatan yang terbangun, dengan keterbatasan kualitas sumber daya manusia dalam kepengurusan GKI Tegalrejo Salatiga ini semakin membatasi tingkat penilaian akan risiko theft of cash yang bisa terjadi.

Kendala dari keseluruhan aktivitas pengendalian antara lain tidak dilakukannya otorisasi persembahan yang telah diberikan di kotak persembahan gereja. Amplop persembahan akan tetap berada di dalam kotak persembahan yang terbuka dan akan diambil oleh bendahara ketika akan dilakukan penghitungan. Kendala lain adalah kurangnya pengawasan pada layar monitor CCTV dan tata letak monitor CCTV yang membelakangi karyawan TU sehingga meminimalisir kemampuan pengontrolan. Kesibukan masingmasing bendahara majelis juga mengakibatkan bendahara jarang melakukan pengecekan terhadap saldo di bank maupun pengecekan rekening koran secara berkala.

Sementara kendala pada tahap informasi dan komunikasi adalah mengenai akses keterbukaan informasi yang dimuat dalam warta jemaat. Pihak majelis gereja harus terus melakukan evaluasi apakah penyampaian informasi melalui warta jemaat ini sudah cukup efektif atau lebih baik menggunakan media verbal melalui woro-woro dan sosialisasi. Selama pengamatan dilakukan, kesadaran jemaat untuk mengambil warta jemaat tidaklah begitu tinggi. Kendala pada komponen pemantauan adalah pengawasan oleh pendeta selama proses penghitungan dan pencatatan persembahan terkendala jadwal pelayanan pendeta yang cukup padat dan mengakibatkan kurang maksimalnya fungsi pemantauan. Kendala lain adalah perlawatan rutin jemaat yang dilakukan klasis diberikan dalam jangka tahunan sehingga memungkinkan fenomena yang terjadi pada saat perlawatan berbeda dengan situasi dan fenomena yang biasa terjadi. Kendala dalam praktik pengendalian internal ini nanti akan dinilai dalam kegiatan audit yang dilakukan oleh anggota jemaat yang berprofesi sebagai akuntan atau auditor.

\section{KESIMPULAN}

Hasil penelitian menunjukan bahwa pengendalian internal atas risiko asset misappropriation - theft of cash pada siklus pendapatan GKI Tegalrejo Salatiga telah terimplementasi dengan baik menurut 5 komponen pengendalian internal menurut COSO. Majelis GKI Tegalrejo Salatiga telah mengoptimalkan upaya pengendalian pada lingkungan pengendalian, penilaian risiko, aktivitas pengendalian, informasi dan komunikasi serta pemantauan untuk memitigasi risiko theft of cash pada penerimaan persembahan. Adapun beberapa kendala masih ditemui seperti majelis gereja tidak sepenuhnya mampu memahami Tata Laksana GKI, majelis gereja masih belum sepenuhnya mampu menilai risiko theft of cash karena belum tersedianya SOP terkait, kurangnya pengawasan pada layar monitor CCTV karena tata letak monitor CCTV yang membelakangi karyawan TU, rendahnya intensitas pengecekan saldo di bank maupun pengecekan rekening koran oleh bendahara, rendahnya kesadaran jemaat untuk membaca informasi di warta jemaat, serta terbatasnya sumber daya manusia dalam kepengurusan 
gereja sehingga tidak mampu memberikan tanggung jawab kepada salah satu pihak untuk menjadi pengawas kegiatan-kegiatan terkait siklus pendapatan yang terjadi. GKI Tegalrejo Salatiga juga melaksanakan kegiatan audit yang dilakukan oleh jemaat yang berprofesi sebagai akuntan atau auditor untuk menilai dan mengevaluasi kinerja majelis gereja selama satu tahun.

Implikasi penelitian ini adalah untuk mendorong jemaat dalam meningkatkan partisipasi dan kepeduliannya terhadap pengendalian internal yang dilakukan oleh GKI Tegalrejo Salatiga, terutama terkait proses penerimaan persembahan dengan memberikan rekomendasi yang membangun. Selain itu, hasil penelitian ini juga dapat dijadikan sebagai salah satu bahan evaluasi bagi majelis GKI Tegalrejo Salatiga untuk memperbaiki dan meningkatkan pengendalian internal yang dilakukan. Implikasi secara teoritis juga bagi akademisi, diharapkan penelitian ini mampu menjadi salah satu acuan dalam pengembangan teori dan penelitian selanjutnya.

Keterbatasan dalam penelitian ini adalah terbatasnya waktu untuk kegiatan pengamatan dan wawancara dengan narasumber. Narasumber memiliki jadwal pelayanan yang cukup padat serta kegiatan lainnya yang mengakibatkan sulitnya pembuatan schedule dengan narasumber. Selain itu, dilakukan pembatasan penelitian dari pihak pengurus gereja, sehingga peneliti tidak berkesempatan untuk bertemu dengan bendahara majelis. Dampak pembatasan ini adalah kemungkinan terdapat beberapa data yang bersifat subjektif karena hanya bersumber dari pendeta. Pandemi yang sedang terjadi juga membatasi waktu dan sarana pertemuan dengan narasumber yang hanya dapat dilakukan dalam waktu singkat.

Berdasarkan uraian yang telah dijelaskan maka saran yang dapat kami berikan kepada GKI Tegalrejo Salatiga yaitu diharapkan GKI Tegalrejo Salatiga dapat meningkatkan praktik pengendalian internal yang telah ada. Saran bagi penelitian selanjutnya adalah melakukan penelitian mengenai siklus yang lainnya, seperti siklus pengeluaran kas. Penelitian selanjutnya juga diharapkan dapat dilakukan pada objek lembaga pemerintah untuk menilai risiko dan pengendalian internal yang diterapkan.

\section{REFERENSI}

[1] E. A. Wibowo and H. Kristanto, "Korupsi dalam Pelayanan Gereja: Analisis Potensi Penyimpangan dan Pengendalian Internal," Integritas, vol. 3, no. 2, pp. 105-136, 2017.

[2] M. M. Meriani and C. D. Wenny, "Penerapan Good Corporate Governance Pada Organisasi Nirlaba Dan Organisasi Profit Oriented," Economic, pp. 1-12, 2018.

[3] M. Rizky and F. A. Fitri, "Pengaruh Keefektifan Pengendalian Internal, Ketaatan Aturan Akuntansi, Penegakan Hukum, dan Perilaku Tidak Etis terhadap Kecurangan Akuntansi," J. Ilm. Mhs. Ekon. Akunt., vol. 2, no. 2, pp. 1020, 2017.

[4] Y. Septiani, "Pendeteksian Fraud Atas Aset Pada PT . ICS," pp. 1085-1090, 2016.

[5] A. I. Sofia, "Masyarakat Sebagai Korban Sekaligus Pelaku Dalam Korupsi di Sektor Pelayanan Publik,” 2020.

[6] S. Wulandari and M. Marwata, "Pengaruh Keamanan Aset Pemerintah Daerah Terhadap Penyalahgunaan Peralatan Kantor: Studi Kasus Di Dinas Pekerjaan Umum Dan Penataan Ruang Kota Salatiga," J. Akunt. DAN BISNIS J. Progr. Stud. Akunt., vol. 6, no. 1, pp. 2235, 2020, doi: 10.31289/jab.v6i1.2802.

M. A. H. Tjungadi and Y. Rahadian, "Akuntabilitas Pelaporan Keuangan dan Pengendalian Internal pada Gereja Toraja ABC," J. ASET (Akuntansi Riset), 
vol. 12, no. 2, pp. 241-264, 2020.

[8] D. Ramdhani, "Peran Keutamaan Organisasi Dan Akuntabilitas Publik Dalam Memengaruhi Kinerja Sektor Publik Di Organisasi Perangkat Daerah Propinsi Banten," J. Ris. Akunt. Terpadu, vol. 11, no. 2, 2018, doi: 10.35448/jrat.v11i2.4261.

[9] U. N. Dewi, N. Fathurrahmi, and D. Puji, "Pengaruh Pengendalian Internal Sistem Informasi Akuntansi dan Profesionalisme Auditor Internal Terhadap Upaya Pencegahan Fraud Dalam Pengelolaan Persediaan Abstrak," vol. 4, pp. 1-17, 2021.

[10] A. K. Kalendesang, L. Lambey, and N. S. Budiarso, "Analisis Efektivitas Sistem Pengendalian Internal Persediaan Barang Dagang Pada Supermarket Paragon Mart Tahuna," Going Concern J. Ris. Akunt., vol. 12, no. 2, pp. 131139, 2017, doi: 10.32400/gc.12.2.17443.2017.

[11] Endiana, "Pengendalian Internal Terhadap Kinerja Perusahaan," $J$. KRISNA Kumpul. Ris. Akunt., vol. 11, no. 2, pp. 179-189, 2020.

[12] D. Rusvianto, S. Mulyni, and I. Yuliafitri, "Pengaruh Pelaksanaan Sistem Pengendalian Internal Pemerintah dan Kompetensi Sumber Daya Manusia Terhadap Kualitas Laporan Keuangan Pemerintah Daerah (Studi Empiris pada SKPD Kota Bandung)," vol. 4, 2018.

[13] I. S. Marifati and U. Ubaidillah, "Sistem Informasi Akuntansi Siklus Pendapatan Pada Usaha Bengkel Budi Barokah Sokaraja," Indones. J. Softw. Eng., vol. 5, no. 1, pp. 44-51, 2019, doi: 10.31294/ijse.v5i1.5863.

[14] Ikatan Akuntan Indonesia, "PSAK 45 : Pelaporan keuangan Organisasi Nirlaba," Akunt. Menengah 1, no. paragraf 08, p. 243, 2016, [Online]. Available: https://blud.co.id/wp/wpcontent/uploads/dlm_uploads/2017/09/P SAK-45-Pelaporan-KeuanganOrganisasi-Nirlaba.pdf.

[15] "ISAK-35-Entitas-BerorientasiNonlaba-21092020.”.

[16] F. M. Bigky and M. Rahmah, "Perlakuan Akuntansi Organisasi Nirlaba Terkait Dengan PSAK No.45 Tahun 2017 Pada Gereja HKBP Maranatha," J. Akunt. dan Bisnis Krisnadwipayana, vol. 6, no. 1, pp. 29-36, 2019.

[17] M. Ali Akbar et al., "Peran Good Corporate Governance dalam Pencegahan Fraud," J. Chem. Inf. Model., vol. 53, no. 1, p. 287, 2019, [Online]. Available: http://dx.doi.org/10.3923/ijss.2016.1.8\% 0Ahttp://dx.doi.org/10.3923/ijss.2015.1 42.152\%0Ahttps://doi.org/10.1016/j.sol ener.2019.02.027\%0Ahttps://www.gold er.com/insights/block-caving-a-viablealternative/\%0A???\%0Ahttp://repositor y.ut.ac.id/6444/1/6-ismawan.

[18] R. O. Dinata, G. Irianto, and A. D. Mulawarman, "Menyingkap Budaya Penyebab Fraud: Studi Etnografi Di Badan Usaha Milik Negara," J. Econ., vol. 14, no. 1, p. 66, 2018, doi: 10.21831/economia.v14i1.18453.

[19] C. Horwarth, "Why the Fraud Triangle is No Longer Enough," Crowe Horwath, 2011. www.crowe.com.

[20] K. S. Danuta, “Crowe's Fraud Pentagon Theory dalam Pencegahan Fraud pada Proses Pengadaan melalui EProcurement," J. Kaji. Akunt., vol. 1, no. 2, pp. 161-171, 2017, doi: 10.33603/jka.v1i2.826.

[21] J. T. Marks, "Playing offense in a highrisk environment," Crowe Horwath, vol. 94, no. 8, p. 14, 2012, [Online]. Available: http://0- 
search.ebscohost.com.wam.city.ac.uk/lo gin.aspx ?direct $=$ true $\& d b=b$ th $\& A N=446$ $18947 \&$ site $=$ ehost-live.

[22] Association of Certified Fraud Examiners, "The Fraud Tree," no. December, pp. 1-13, 2016.

[23] A. A. K. F. Udayani and M. M. R. Sari, "Analisis Pengaruh Moralitas Individu, Asimetri Informasi Dan Pengaruh Pengendalian Internal Dan Moralitas Individu Pada Kecenderungan Kecurangan Akuntansi," E-Jurnal Akunt. Univ. Udayana, vol. 18.3., pp. 1774-1799, 2017.

[24] M. Siahaan, H. Umar, and R. B. Purba, "Fraud Star Drives to Asset Misappropriation Moderated by Internal Controls," J. Southwest Jiaotong Univ., vol. 54, no. 4, pp. 1-10, 2019, doi: 10.35741/issn.0258-2724.54.4.24.

[25] A. I. Zahari, J. Said, and R. Arshad, "Organisational fraud: a discussion on the theoretical perspectives and dimensions," J. Financ. Crime, vol. 27, no. 2020, 2020.

[26] M. Bakri, N. Muhamad, and J. Said, "Mitigating asset misappropriation through integrity and fraud risk elements: evidence emerging economies," J. Financ. Crime, vol. 24, pp. 242-255, 2017.

[27] S. Kazemian, J. Said, E. Hady Nia, and H. Vakilifard, "Examining fraud risk factors on asset misappropriation: evidence from the Iranian banking industry," J. Financ. Crime, vol. 26, no. 2, pp. 447-463, 2019, doi: 10.1108/JFC01-2018-0008.

[28] J. P. Kennedy, "Asset misappropriation in small businesses," J. Financ. Crime, vol. 25 , no. 2 , pp. 369-383, 2018, doi: 10.1108/JFC-01-2017-0004.

[29]

Y. Septriyani and D. Handayani, "Mendeteksi Kecurangan Laporan
Keuangan dengan Analisis Fraud Pentagon," J. Akuntansi, Keuang. dan Bisnis, vol. 11, no. 1, pp. 11-23, 2018, [Online]. Available: http://jurnal.pcr.ac.id.

[30] M. Aynurrahman, "Analisis Sistem Pengendalian Internal Aset Tetap Institusi ( Studi Pada Universitas Wiraraja )," 2019.

[31] A. Schandl and P. L. Foster, "COSO Internal Control - Integrated Framework: An Implementation Guide for the Healthcare Industry," COSO - Comm. Spons. Organ. Treadw. Comm., no. January, p. 5, 2019, [Online]. Available: https://www.coso.org/Documents/COS O-CROWE-COSO-Internal-ControlIntegrated-Framework.pdf.

"Internal Control - Integrated
Framework," COSO - Committee of
Sponsoring Organizations of the
Treadway Commission, 2013.
https://www.coso.org/Documents/99002
5P-Executive-Summary-final-
may20.pdf (accessed Mar. 27, 2021).

"Internal Control - Integrated Framework," COSO - Committee of Sponsoring Organizations of the Treadway Commission, 2013. https://www.coso.org/Documents/99002 may20.pdf (accessed Mar. 27, 2021). 